\title{
The Criminal Liability for the Electronic Exploitation of Children under the Qatari Law: A Comparative Study
}

\author{
Mus'ab Turki Ibrahim Nassar
}

\begin{abstract}
The study aimed at the status of the Jordanian gender and the gender aspect of children, which represents a problem in the General Electronic Law of 2014, the seventh gender in criminalizing the use of child sex, sex. And the research has reached the Qatari legislator to put in place special and independent texts that deal with crimes, sentences, the body, the body, the body, and the commercial aspect of human beings, any other unlawful information that is considered an offense that raises the criminal responsibility of the information network service providers, suppliers, providers and publishers if this is proven. Finally, the assistant researcher in the postal industry, the fifth stage, the second stage, technological production, the first stage, the first stage, the second stage Keywords: Child Exploitation Crime, Qatari Jordanian Law.
\end{abstract}

DOI: $10.7176 / \mathrm{JEP} / 11-25-06$

Publication date:September $30^{\text {th }} 2020$

\section{Introduction}

The acceleration of massive technological and technological progress, the emergence of cyberspace and modern means of communication such as fax, the Internet and other forms of electronic communication via satellites exploited by the perpetrators of cybercrime in the implementation of their crimes, which are no longer confined to the territory of one country, but exceeded the borders of countries, which are innovative and innovative crimes that represent a form of Criminal intelligence, It is difficult to include them in the traditional criminal descriptions in national and foreign criminal laws, and in terms of what is related to the fragility of the procedural prosecution system that seems to be limited to absorbing this new criminal phenomenon, whether in terms of criminal prosecution within the framework of national laws or in the field of international criminal prosecution (Ashari, 2006).

The gravity of this crime is highlighted by the fact that it is directed at a large segment of consumers, regardless of their business or gender. Rather, the risk increases even more when such pornographic materials are published on the Internet to children or make them a place for it, which constitutes material and moral harm, which requires the intervention of the legislator. to provide protection for children.

\section{Research problem:}

The research problem is represented in the Qatari e-crime law of 2014, he mentioned a single article to criminalize sexual exploitation of children, which is the seventh article criminalizing the use of electronic means for sexual exploitation of children, the legislator has criminalized the use of the information system or information network, which is the method of committing the crime in establishing or Preparing, preserving, processing, displaying, printing, publishing, or promoting pornographic activities or works. However, this treatment has in some places lacked consideration of the need to pay attention to the practical and technical aspects that are characterized by electronic means, which may lead to weak desired protection from Beyond codifying this text, accordingly, we had to research and scrutinize the extent of the Qatari legislator's failure to protect children from sexual exploitation, hence the problem of this current study is that it tries to answer the main question that is centered on it (What are the deficiencies in dealing with exploitation Sexual childhood in Qatari legislation?). This main question is divided into several sub-questions, which are as follows:

What is the concept of child pornography and sexual exploitation?

- How big is the phenomenon of electronic sexual exploitation of children? What are the electronic means to lure children?

What is the position of the Qatari Cyber Crime Law regarding criminalization of pornography and sexual exploitation of children?

What is the position of other Qatari legislation on criminalizing pornography and sexual exploitation of children?

What is the position of comparative legislation on criminalization of pornography and electronic sexual exploitation of children?

\section{Research objectives:}

The research aims to achieve the following goals:

- Understand the concept of pornography and sexual exploitation of children.

- Determine the size of the phenomenon of electronic sexual exploitation of children, and electronic means to lure 
children.

- Explaining the position of the electronic crime law and other Qatari legislation against criminalizing pornography and electronic sexual exploitation of children.

- Explaining the position of the comparative legislation regarding the criminalization of pornography and electronic sexual exploitation of children.

\section{Research importance:}

The importance of this research lies in that it sheds light on the most important modern and contemporary crimes, especially those related to the information technology phenomenon, which are crimes of electronic sexual exploitation of children, which have spread dangerously in all countries of the world, which made the children of the world vulnerable to falling under the threat of these crimes through the use of technology means The information that has become available to everyone with ease of use, therefore the importance of this research is reflected in the definition of these crimes as they represent a new type of crime that societies have not been familiar with before, especially Arab societies, as well as the importance that is manifested in uncovering the types of crimes of electronic exploitation of children, causes and motives Behind its spread and commission, the importance is also through clarifying the mechanisms and perceptions needed to address these crimes and the difficulties that prevent them from being dealt with legally.

\section{Study methodology}

The nature of the subject matter of the study imposed on the researcher to take a certain, where the researcher will approach an integrated vehicle adopting a methodology for a comprehensive framework for analysis, and the most prominent of these curricula.

1. Descriptive approach: This approach means studying the phenomenon as it actually exists, describing it accurately, describing its characteristics, and giving it a digital description through numbers and tables that explain the amount of this phenomenon, its size, or the degree of its association with other phenomena.

2. Analytical approach: This approach is concerned with defining and evaluating the parts that make up the whole for any issue, and it is a means to obtain rich and new knowledge. It is understood that the analytical approach takes analysis with different images and levels depending on the nature of the subject of the research, and the multiplicity of analysis processes is a condition for providing a more general and comprehensive understanding The issue under study, as it works to analyze the topic into simple elements or divide the thing into its components and units, as well as by analyzing and explaining the opinions of scholars and researchers on the subject of the thesis.

3. The comparative approach: This is through reviewing the texts of international agreements and national laws related to the subject of the study, analyzing these texts and describing them in an accurate description, explaining all aspects related to the variables of this study and its criticism.

The definition of the 'age of child' as a 'person below the age of 18 years'10 was taken over from the 2004 Framework Decision, which at the time was a considerable innovation. 11 Yet this standardization of age, while being in line with other international instruments, 12 had caused internal incoherence in national criminal legislation on sexual offences. The disaccord between the standard age of child as 18 for the purposes of criminalizing sexual offences against children required by EU law and national provisions on age of consent for engaging in sexual activities was difficult to reconcile at the national level.13 This at times meant that while a person under 18 years could consent to sexual activity, any other activity related to making or distributing pornographic images of him or herself was now criminalized. The 2011/93 Directive overcomes this problem in the following way. For the purposes of adequate protection of minors from exploitation, the age is fixed at under 18 years. Yet it is in the discretion of the Member States to decide whether to criminalize the possession or production of pornographic material by children who have attained the age of sexual consent, provided that the material is for private use and is the result of consensual sexual activities and did not involve any abuse.14 The Directive has considerably broadened the material scope of the legislation by extending the notion of 'child pornography' beyond pornographic material involving children to material depicting adults who look like children (youthful adult pornography) and computer generated pornographic material involving children (virtual child pornography).15 It is apparent that with the inclusion of the virtual child pornography category the justification for criminalizing this aspect of social conduct has shifted from the 'harm' caused to the child depicted in the pornographic material, and moved away from the protection of children. Here the rationale for criminalization is to denounce a behaviour that might be used to encourage or seduce children into participating in such acts and hence creating a subculture in which child abuse is accepted. While the parallel provisions of the Council of Europe's Cybercrime Convention also reinforce this broadening of criminalized conduct, 16 it is worth mentioning that most European jurisdictions did not have corresponding legislation prior to the Directive and the Cybercrime Convention. It is of interest to note a similar provision of the United States' Child Pornography Prevention Act 1996 (CPPA) was held to be unconstitutional by the United States Supreme Court as violating the First Amendment 
right to free speech.17 In Europe, no similar constitutional debate arising from the broadening of the ambit of criminalized conduct have erupted, and the preamble of the Directive 18 explicitly denies that material with child pornography content could have any construction as an expression of an opinion. At the same time, the boundaries of legislation were certainly pushed to novel areas.

\section{The first topic}

\section{The concept of sexual exploitation of children}

The sexual exploitation of children through electronic means and the Internet in particular was a global problem due to its widespread presence throughout the world, in addition to the ease of doing it despite all efforts made to combat it, and the crime of sexual exploitation of children via the Internet "or what is called visual prostitution or pornography", It is one of the crimes of exploitation of children, and it is one of the worst crimes of the media and communication of all kinds because it actually exploits children. The era has witnessed in recent decades, as well as the lack of cross-border punitive legislation, with which the traditional criminal law stands unable to confront it. (Sulieman, 1999).

So it states split confront this crime, but independent punitive legislation or traditional penal laws, as this represents a crime, a clear violation of the rights of the child, as the child is forced to exploit him and raised the crime to extend attainable and death. This crime is intended to depict any child - including a picture, movie, video, or drawing by any means, electronic, mechanical or computer, through which he engages in real practice or simulated explicit sexual activities or any depiction of the sexual organs of the child to satisfy the sexual desire essentially whether he showed a real child or It seems real.

In the Arab world, the matter remained until recently, far from the researchers 'interest, and the first conference dealing with this phenomenon was held in (Rabat / Morocco in 2001) in this regard. The conference recommended attention to gathering information and data on the topic of sexual exploitation of children, while in Qatar the first was hosted An international conference on child protection in Qatar in 2020 (Khalil, 2006). In Jordan, the first conference was held in 2003 under the title "To break the silence" which dealt with violence against children, including sexual exploitation of them. (Shwish, 2017).

Therefore, the importance of research is evident in that it deals with a sensitive issue, as dealing with this issue is not familiar in Eastern culture, and therefore it may contribute to introducing society to that issue, which is one of the most important issues that presented itself on the agenda of countries, especially those interested in children's rights, and in the beginning and through This topic must be determined and sexual exploitation of children by electronic means, by dividing the chapter into the following two requirements:

The first requirement: the connotation of child abuse in accordance with international agreements

The second requirement: the significance of sexual exploitation in accordance with the Qatari and comparative legislation.

The first requirement

The meaning of child exploitation in accordance with international conventions

Due to the emergence of pornography and pornography in the Internet and the direction of its dangers towards children, the international community began to intervene to put an end to it, especially as it has been increasing day by day, and this was evidenced by the holding of the International Conference to Combat Sexual Exploitation of Children in 1999 in us, which came with some recommendations and perhaps the most important of them: (Vienna Convention for Combating Sexual Exploitation) For children in 1999).

1. Promote norm-setting for behavior by Internet service providers

2. Encourage the creation of citizen hot sites to report child pornography online.

3. The national legislator promulgating legislation related to the criminalization of sexual commerce on the Internet for the purpose of providing legal protection for the child, and that the state should set rules that address a definition, even a specific one, for this crime that takes into account the intentional possession of the image of children and their disposition, whether it is distribution, production, import, export Etc. And all this is done under the framework of the International Convention on the Protection of the Child.

4. At the international level, encourage international cooperation to combat the crime of sexual exploitation of children via the Internet, by establishing special units for this purpose and preparing a special training program for rehabilitation in this field.

Some international instruments have been concerned with the definition of pornography and sexual exploitation of children. Child pornography has defined the Optional Protocol to the Convention on the Rights of the Child on the sale of children, child prostitution and child pornography in Article 2 / c as: "Photographing any child by any means practiced Acting in reality or by simulating explicit sexual activities or any depiction of a child's sexual organs, mainly to satisfy sexual desire. (Adel, 2013).

The European Convention on Cybercrime, which entered into force in 2004, also defined Article 9/2 / a of child pornography as: "Any pornographic material depicted in a visual manner is a minor sexual act."

As for the European Union directives related to protecting children from sexual abuse and exploitation, it 
separated two terms: (Eid, 2001).

First: child pornography and defined as (any material visually depicting a child or a person who appears to be a child engaged in explicit sexual act or simulated sexual or perception of its members to be used for sexual purposes basically).

The second: Child pornography, and defined it as (a direct display that targets a segment of the public and uses information and communication technology to display a child engaged in real sexual activity or simulation or offer the sexual organs of a child to use for sexual purposes in the first place).

Except for these two definitions of child pornography and pornographic offers, the directives also counted as child exploitation, ie profit, cause, use, coercion, or threat to a child to involve him in pornographic performances, or even just attending pornographic presentations in which a child participated, such as child sexual exploitation, and then the guidance returned To confirm in the context of extending the term sexual exploitation of children, which is an expansion of benefit because it includes within the sexual exploitation any possession, possession, or attempt to own or possess pornographic material related to children, or any attempt to publish, distribute, display, produce or equip it. (Khalil, 2006).

But what is taken on the definition of the directives is that it limits the sexual exploitation of children to one form: child pornography or child pornography and related possession, possession, coercion, profit, or cause the production, distribution, publication, or even viewing of such material. He did not address other aspects of exploitation, and perhaps this reflects in one way or another the expansion of this pattern of sexual exploitation of children after the use of modern means of communication in such behavior.

The 2007 European Council agreement on the protection of children was also concerned with the topic of sexual exploitation and sexual abuse of children (adopted by the Ministerial Committee on July 12, 2007 during the 1002 meeting of representatives of ministries and entered into force on July 1, 2010 and was made available for signature by the member states of the European Council and non-member states that contributed In extending the scope of the agreement, the number of countries that have ratified the agreement has reached 24 , and 21 countries have signed the agreement and have not yet ratified it.

However, it did not use the term sexual exploitation, and instead it used several terms and gave each of them a specific definition, and the abundance of the terms used with determining the meaning of each of them in this agreement is a factor that made the agreement distinct from other agreements related to this subject, and the meaning of those terms can be determined It was mentioned in that agreement according to the following:

1- Sexual assault: It means: "sexual activities with a child, whether the practice occurred as a result of coercion, threats, or the use of trust, authority, influence, or as a result of a child's mental or physical weakness, but the sexual abuse to which this article referred is related to two topics. The first determines the age of exercise Sexual activities, as some internal laws, such as Swiss law, allow those who have attained the age of 16 years to engage in sexual activities... The second issue is that sexual assault does not deviate to consensual sexual practices when they take place between minors "(see Article 18 of the European Convention).

2- Child prostitution: The agreement defined it as "using the child for sexual activities in exchange for money or any other form of reward or compensation or cutting a promise to pay regardless of whether the payment was made or the promise was promised or compensation was provided to the child or someone else." "The child's exploitation of prostitution implies the use of the child, or his or her urging to participate in or prostitution in prostitution, or the child's use of prostitution. The definition did not refer to the consent of the child, which means that the consent of the child is not respected here and that even if issued, the act remains within the framework of the child's exploitation of prostitution and the essence of discrimination here, that the convention respected the child's personal freedom to engage in sexual activities, that freedom issued by an incomplete will . (Article 19 of the European Convention).

3- Child pornography exploitation: It is intended to "portray any child by any means that engaged in real practice or simulation of explicit sexual activities or any depiction of the sexual organs of the child mainly to satisfy sexual desire, but the agreement established restrictions on this definition including the right of children to produce or possess material Child pornography does not exist without that being a form of exploitation for them and this restriction falls within what we indicated to him in respecting the will of the child. " (Article 20 of the European Convention).

4- Exploiting the child in a pornographic show: It means "using a child, urging him, forcing him or making use of him in a pornographic show or watching a child porn show, and it seems clear that there is an expansion in the definition of child pornography abuse that exceeds the limit of participation to just watching a porn show that he performs." The child with a clear indulgence regarding the right of the parties to limit the inclusion of the definition merely for the sake of viewing, and perhaps this indulgence is based on the fact that just watching a child in a pornographic show does not cause the child to be affiliated with any sexual exploitation, sexual assault or sexual abuse, not from afar or from near, or that it is easier Matters "(Article 21 of the European Convention).

5- Add to that pornography represents a pillar of the economy in some countries, but reflection in this article 
would raise a question of how a person can view a pornographic offer for a child even though the use of children, urging them or forcing them to make such offers is not permitted in That country, and it appears once again that the agreement has attempted to harmonize ideals and ideals that prevent the sexual exploitation of children in any form and the existing patterns of exploitation and therefore used the past tense (Abdullah, 2002).

6- Corruption of the child: It is intended to "intentionally urge the child, for sexual purposes, to witness sexual assault or sexual activities even if he does not participate in them, and corruption of the child is a new term that was not mentioned either in the Convention on the Rights of the Child or in the protocol attached to it, and well the treaty did when it criminalized corruption. The child because corruption is often followed by the exploitation of the child, he does not imagine that a person urges a child to witness sexual assault or sexual activities without intending to use them to exploit it. (Article 22 of the European Convention).

7- Inquiring the child for sexual purposes: It means "an adult person through information and communication technology offering to meet with a specific child or engage in sexual activity with a child or to exploit him in pornographic materials and to follow this offer with material actions that led to this to meet" and the term "grooming" term is a leak to the agreement from International jurisprudence, which is just as new as the corruption of a child. (Article 23 of the European Convention).

8- $\quad$ With regard to the exploitation of children in pornography on the Internet, it is considered a form of sexual exploitation of children, as it adopts many technical means and shows the child engaging in explicit sexual activities, real or simulated, or reveals some parts of his body in an obscene way that causes him to arouse sexual desire or pleasure. (Journal of Human Rights, Promotion and Protection of All Human Rights, Civil, Political, Economic, Social and Cultural, Including the Right to Development Report submitted by Majeed, Najat Mualla, Special Rapporteur on the issue of the sale of children *, child prostitution and child pornography, p. 7).

The second requirement

The connotation of pornography and sexual exploitation of children according to Qatari and comparative legislation

There was no definition in pornography of Qatar for pornography and sexual exploitation of children, and there was no enumeration of what is considered from these acts like that of most of the legislations that criminalized these acts, nor was there a definition of these terms in the Qatar Penal Code despite its criminalization in Article (292) and article (296) From it, except that a definition of sexual exploitation of children can be deduced from what is mentioned in these articles. Sexual exploitation of children is: "Whoever makes, imports, exports, possesses, attains, or transfers with the intention of exploitation, distribution, or presentation in writing, in print, or in writings Others, drawings, pictures, movies, symbols, or other things that violate public life or morals, and everyone who announces something of that, or offers it to children (male or female), sold it, leased it, or offered it for sale or for rent even if it is not Publicly, and whoever distributes it or submits it for distribution by any means. Accordingly, the researcher believes that the Qatari legislator did not explicitly and explicitly address the definition of pornography and sexual exploitation of children, but merely criminalized sexual exploitation of children.

Among the legislations is the one that was adopted to define child pornography, the Omani law against crime of information technology, which was stricter by Royal Decree No. 12/201, which defined pornography as: "the content of libido," as stated in Article (10/3) with the phrase "child pornography, the definition of pornography On children in the Optional Protocol to the Convention on the Rights of the Child and child pornography. "

In another direction, we find the Canadian Penal Code of 1985 and amended for 2015, defined by Article (163/1) child pornography as: "pornographic pictures, films and all virtual images, whether they are done by electronic or mechanical means, which: (Al-Nawaisah, 2017) .

1. Show a person depicted as less than eighteen years old who has sexually explicit activity.

2. Any writing, material, virtual photography, or sound recording that supports or provides advice about sexual activity with a person who has not reached the age of eighteen.

3. Any written material describing for sexual purposes sexual activity with a person who has not attained the age of eighteen years.

4. Any phonogram, describing for sexual purposes sexual activity with a person who has not attained the age of eighteen years.

Accordingly, the researcher sees that there is a difficulty in defining the concept of porn in general, and child pornography in particular, there is no agreement on its concept, especially as it is no longer a private matter for a specific country.

The second topic

The legal basis for criminalizing electronic sexual exploitation of children in Qatari legislation

Through this topic, the justifications for criminalizing sexual exploitation of children will be clarified, then reviewing the legal texts that criminalized this type of exploitation in Qatari and comparative legislation, as follows: The first requirement: the reasons for criminalizing electronic sexual exploitation of children 
The second requirement: the legal structure of the crime of electronic sexual exploitation of children

The first requirement

Reasons for criminalizing electronic sexual exploitation of children

The immature physical, psychological, and mental nature of the child makes it ready to be easily susceptible to crimes of electronic sexual exploitation (Al-Ubaidi, 2004), and therefore the legislator has imposed strict substantive and procedural rules to avoid harming him physically, psychologically and mentally. The Qatari legislator, when he criminalized the exploitation of children, took into account the child's physical condition and physical strength, which does not allow him to resist everything that would harm his weak body, or to defend himself in the event of abuse or kidnapping, in addition to that the child at this stage is Unable to distinguish between what is acceptable and what is unacceptable, and what is harmful and what is beneficial, hence the urgent need to issue a set of legal texts that would protect the child in his body and mind. (Attia, 1998).

If the sexual exploitation of children is associated with its concept of unlawful use at the expense of their rights, in order to cause harm to their body and mind as we saw in the past, then what is the basis of this sexual exploitation ?, and can it be linked to the status of weakness in terms of physical and physical strength or is this basis finding its legal basis In terms of weakness in terms of will and discrimination, this will be examined as follows:

First: The reason for criminalization related to the level of weakness in terms of the physical and physical strength of the child

The child's life has something called the hypothesis (the critical period), according to which the transition from a certain stage of growth to another stage must not be obstructed by his physical development, this last formative aspect is the product of the chemical reactions that lead to the growth of the external organs as well as the internal organs . (Al Jasmani, 1994).

Therefore, the child must be cared for, cared for, cared for and protected physically, which is what the Qatari legislator did when he surrounded this weak creature with care, care and legal protection to secure his weak body (Al-Marri, 2012), and this is evident through the legal texts that were developed to protect the child from sexual exploitation, where he The Qatari legislator determines the age of children who are subject to one of the crimes of sexual sexual exploitation, as the text of the Qatari law was explicit in Article (292), where this article criminalized the sexual sexual exploitation of those under the age of sixteen, and in the text of Article (7) of the Electronic Crime Law The Omani has set the age of eighteen for those who fall into this type of crime.

From the foregoing, we note that the basis related to the child's physical or weak strength in terms of physical strength does not clearly explain the purpose of the legislator from criminalizing sexual exploitation of children, which requires that the basis related to the child's interest in terms of the ability to perceive and distinguish be discussed.

Second: The reason for the criminalization related to the level of vulnerability in terms of will and discrimination of the child

The idea of the legal reason or foundation associated with the status of weakness in terms of will and discrimination is due to the criminalization of the actions that take place on the child due to the incomplete mental formation of the child, as he is unable to distinguish and realize the age-related perception (Attia, 1998). Sexually, it expresses the integrity of the mental and psychological components of the child who exploits his moment and exploitation or sexual assault, so the Qatari legislator sought to define the legal basis that is related to the status of weakness in terms of will and discrimination and linking it to the property of discrimination and perception, and freedom of choice, which are available only in a person He will have reached a certain age to qualify for recognition.

Accordingly, we find that the Qatari legislator has stipulated that in order to have sexual exploitation of children, that the child victim is no more than eighteen years of age, because the mental or mental activity of the child does not grow on a continuous level but rather develops from one pattern to another. It is also clear that the Qatari legislator in his dealings with child victims of sexual exploitation has taken into account the element of the body and mind, and did not separate them as long as the child's under-minded mind caused him not to realize that he would be sexually exploited, or he would be a victim of exploitation because of his ability to do something .

Third: The reason for the criminalization associated with the negative effects of sexual exploitation of children Sexual exploitation of children is the main concern at the present time, as it is an issue that has been affected by the veil of silence for many years, even though it is sensitive to shaking the soul and morals (Toubasi, 2005). Sexual exploiters of children do not hesitate to insult children and their abuse and exploitation in many forms and manifestations, where we find that sexual exploitation of children may come from their closest relatives, or from their operators or from where it is assumed responsibility for the care and protection of children (Al-Muhtar, 2008). We find that the criminalization of sexual exploitation of children is due to the great risk involved in the sexual exploitation of children, which is reflected in the health and behavior of the child and then requires greater attention from psychological specialists to know the special problems that accompany the acts of sexual exploitation of children, because children are the most deserving of the human rights recognized by instinct and law Heavenly, and confirmed by international documents and national legislation, as juveniles are in need of special care by the 
criminal justice authorities that must aim to provide justice and judicial care for every juvenile, and that this treatment is in the context of the pursuit of an important goal which is child protection, reform and evaluation of any Negative behavior. (Darwish, 2016).

The youth and young groups constitute the majority in the Qatari society and the fact that the youth are the nucleus of the basic infrastructure of the society and the future of its future and the hope of a bright tomorrow. The Qatari legislator has paid great attention to this category, as it has unique texts that protect it, safeguard its freedoms and defend its rights. Regulating and protecting the rights of children and women, such as the Family Law No. 22 of 2006 in its provisions on custody, vision and other rights related to children and women, Law No. 25 of 2001 regarding compulsory education, and Law No. 22 of 2005 regarding the prohibition of bringing, operating, training and engaging children in a race Camel and Penal Code No. 11 of 2004, and Labor Law No. 14 of 2004 whose provisions all included giving special care and attention to the rights of both children and women.

On the executive and institutional side, the establishment of the National Human Rights Committee came by Decree Law No. 38 of 2002 , as one of the most important circles for the promotion and enrichment of the march of human rights in the State of Qatar.

The second requirement

The basis for criminalizing child sexual exploitation

That the protection of children from pornography and sexual exploitation contained in the Penal Code is amenable in many forms to committing by electronic means, and it is possible that sexual exploitation of children constitutes a crime of human trafficking subject to the provisions of the Human Trafficking Law, and it can constitute a crime mentioned in the Communications Law, and accordingly, we will show in The requirement to criminalize child pornography and sexual sexual exploitation in the Cyber Crime Law and in other legislation, through the following: The first branch: Criminalization of the sexual exploitation of children in the electronic crime law Criminalization of pornography and sexual exploitation of children is mentioned in Article (7) of the Qatari Cyber Crime Law (corresponding to the text of Article (9 / A) of the Jordanian Cyber Crime Law), where the text of the article came as follows: "He shall be punished by imprisonment for a period not exceeding five years, and by a fine Whoever does not exceed $(500,000)$ five hundred thousand riyals, whoever produces pornographic material about a child by means of information technology, or imports, sells, or offers to sell, use, trade, transfer, distribute, send, publish, make available or broadcast pornographic material About a child by means of information technology.

Whoever possesses pornographic material for a child shall be punished with imprisonment for a period not exceeding one year, and with a fine not exceeding $(250,000)$ two hundred and fifty thousand riyals, and any of the crimes punishable in this article shall not be taken into account with the consent of the child. The rule of this article is for everyone who has not completed the age of eighteen years of a full Gregorian year.

Thus, the Qatari legislator has criminalized the use of the information system or the information network for the purpose of child prostitution or pornography. Among these crimes is to send, publish or distribute pornographic acts or broadcasts related to sexual exploitation, and through the text of the previous article, it becomes clear to us that the material pillar in it is to send or publish, and that what was sent or published takes three forms, it may be audible, Or readable, or visible, and that includes pornographic or sexual exploitation, pornographic or sexual exploitation of a person who has not reached the age of eighteen (a child), and that transmission or publication be done through an information system or information network (electronic means) Also, this intentional crime does not accidentally occur.

Criminal behavior in this crime is the act of sending or publishing, as the legislator has criminalized both behaviors and doing one of them is sufficient for the activity that constitutes the crime and each of the two behaviors has a different meaning in terms of scope, so transmission means providing a person or group of people with pornography, or that relates to the sexual exploitation of children. As for publishing, it means broadcasting this article without specifying recipients, and without discrimination for who can view it, the difference between sending and publishing lies in the personal domain of those who can see what is sent or published only (Al-Asadi, 2015).

The legislator has equalized the two verbs, so it is equal for the perpetrator to send or publish, and a person may send and the recipient publish, then the criminal behavior is achieved by doing any of the two verbs, and the transmission may be done by one or several acts at the same time, or at different times, and in this case If the material submitted is related to the same content, then all of these acts constitute one consecutive crime.

And the content submitted is audible. Any audio or reading material; Any written material, no matter the language in which the content is, and the content may be visible in the form of pictures or videos. However, the transmission or publication must take place through an information system or the information network, and in this way the legislator specified the method of committing the crime by electronic means, and the Qatari electronic crime law defined the information system as: "a set of programs and tools designed to create data, or electronic information, or send it, Or receiving, processing, storing, managing or displaying it by electronic means. " The information network means: "a link between more than one means of information technology, to obtain and exchange 
information, including private and public networks and the global network" the Internet "(text of Article (2) of the Electronic Crime Law). According to the advanced definitions, all electronic means used For posting and publishing, it is suitable as a means to commit a crime, and the means is an essential component for the commission of this crime, the legal model of which is not fulfilled without its availability, and if it is possible to apply to the act another criminal description.

In addition to sending and publishing, the Qatari legislator has better criminalized the electronic circulation of pornographic content related to children, because this may be done without the act of sending or publishing, such as circulating with separate electronic memories, or electronic cylinders, as well as the crime of possession of pornographic content if it is related to children, or the production or import Or the sale of electronic pornography related to children, which is in accordance with many Arab legislation. (See Article (10) of the Bahrain Information Technology Crime Law No. (60) of 2014, Article (7) of the Qatari Cyber Crime Law No. (14) of 2014, and Article (14) of the Oman Information Technology Crime Law No. (12) (For the year 2011 when we find that all of these laws have criminalized the electronic circulation of pornographic content related to children).

Also, the material sent or published electronically must include pornographic acts, or relate to sexual exploitation to those who did not complete the age of eighteen or through it for the consent of the child in these crimes, i.e. whoever meets the capacity of the victim, who is any person who has not completed the age of eighteen (the child ), Regardless of any consideration related to sex or nationality, it is equal for the child to be male or female, Jordanian or foreign; Because childhood protection in general, and child consent is not accepted, there is no consideration for such satisfaction. The child in this crime is a victim of it, he does not count with his consent, and is not asked under any form of criminal participation, and does not prevent the text of Article (7) from the Qatar Electronic Crime Law, if what was published or sent related to pornographic acts among persons under eight Ten years of age, or whoever sent or published less than eighteen years of age.

This crime does not occur except by intent, so the perpetrator must come to the criminal activity while knowing his truth, and that the published or sent content includes pornographic acts or related to sexual exploitation, and that it concerns a person who has not completed eighteen years of age, and since this crime is one of its elements described in the victim Concerning the age, knowledge about it is necessary and the offender may argue that he is not aware of the true age of the victim, and that he believed that the pornographic content of a person over the age of eighteen, because the Qatari legislator did not criminalize electronic porn in general, as did some other legislation that Electronic pornography has criminalized in general, and has increased the punishment when it comes to a child, (from the legislation that criminalized the electronic circulation of pornographic content in general, and increased the punishment when it comes to children, Omani Information Technology Crime Law (Article 14), and Bahraini Information Technology Crime Law (Article 10) We believe that the approach of these legislations is more correct than the approach of the Qatari legislator to achieve protection for public morals and ethics against obscene and spoilers of public morals that are circulated electronically.

In order for the elements of the criminal intent to be complete, the criminal activity must be committed voluntarily, and the criminal intent required in this crime is a general criminal intent after its availability that does not matter to the motivator to commit the crime, so the motives are sexual, commercial or other motives.

It is worth mentioning when referring to the Jordanian e-crime law that we have taken a good and advanced course in protecting the child from sexual exploitation, when stipulating the criminalization of the use of electronic porn to influence children and the disabled, as Article (9/b) of the Jordanian e-crime law stipulated that: "Whoever intentionally uses an information system or information network to create, prepare, preserve, process, display, print, publish or promote pornographic activities or actions for the purpose of affecting those who are not yet eighteen years old or who is mentally or mentally disabled, is punished. Or directing or inciting him to commit a crime by gypsum for a period of no less than two years and a fine of no less than (1000) thousand dinars and not more than (5000) five thousand dinars.

It is clear to us from the text of Article $(9 / \mathrm{b})$ that the legislator aims to protect children and the mentally or mentally disabled from the influence of pornographic content on this group and their exploitation for the commission of a crime, although we believe that the first of that is to protect this category from accessing pornographic content and criminalization Directing or placing pornography in the category of this category, and leaving the issue of influence, guidance, and incitement to commit a crime, even if it is through the pornographic content of the general rules of criminalization and punishment.

We find through the text of Article $(9 / \mathrm{b})$ also that the Jordanian legislator has followed in the criminalization a method of alternating criminal behavior that is based on the census in criminal activities, and that any of these activities is sufficient for the occurrence of the crime if other elements are available, the legislator has criminalized the use of the information system or Information network, which is the means of committing crime in creating, preparing, preserving, processing, displaying, printing, publishing or promoting pornographic activities or works. The similar pluralism in terms of legal value came as a precaution to escape criminalization, even though the perpetrator may commit this crime with more than criminal behavior.

Creation means the creation of pornographic content by electronic means, i.e. creating something that did not 
exist, such as pornographic videos, pictures, e-writings or audio clips. As for preparation, it means obtaining pornographic content without interference from the perpetrator in finding it. As for the electronic preservation of pornographic content, it is achieved by every means it uses to acquire pornographic content electronically, such as downloading this content from a pornographic website and keeping it in an electronic memory. (Al-Asadi, 2015).

And treatment is in the offender's intervention in making modifications to this content or transferring it from one form to another, and it requires technological skills from the actor and presentation in every way through which the content is made available to inform this category of it. Printing means obtaining material extracts of pornographic content, such as printing pictures or pornographic writings. With regard to publishing, it means broadcasting pornographic content using electronic means without specifying the recipients and without discrimination for who can view it. Promotion as a term that has a more precise meaning than just publishing is only possible by offering pornographic content, either public or private, but it also requires that the promoter seeks to communicate and encourage pornographic content to (recipients, 2005).

It would be preferable if the Qatari legislator took the course of the Jordanian legislator to criminalize also the sexual exploitation of children who are physically or mentally handicapped, because they are the most caring group, because if the category of children depends on determining the age that the Qatari legislator took, which is not completing eighteen years of age, For persons who are over the age of eighteen and who suffer from a psychological or mental disability, the officer is determined according to the medical standard, as the age range is narrower than the scope of the disability; Because it depends on a time standard, people who have a psychological or mental disability and have not completed eighteen years of age are included in the category of children. "(International conventions and agreements took care of the rights of persons with disabilities, and set definitions for them in more than one place. The International Declaration on the Rights of Persons with Disabilities issued by The United Nations in 1975 Disabled: "Every person cannot by himself fulfill his individual or social needs, in whole or in part, for organic or inorganic deficiencies in his physical or mental capabilities." The International Convention defined protection and promotion of the rights and dignity of persons with disabilities issued by the United Nations in 2003. Persons with disabilities are: "People who suffer from a physical, sensory or mental deficiency or deficiency that constitutes a barrier or impediment affecting a person's relationship with his environment, whether temporarily or permanently, even if it results from economic or social conditions or is exacerbated by them." The agreement is known The International Rights of Persons with Disabilities, approved by the United Nations General Assembly in 2006, states that persons with disabilities are: "Everyone who suffers from long-term disabilities, be they physical, mental, mental or sensory, which may prevent them when dealing with different Barriers from the efficiency of their full and effective participation in society on an equal basis with others.

In terms of internal legislation, the Egyptian legislator defined in the second article of the Disabled Rehabilitation Law No. (39) for the year 1975 the handicapped as: "Every person has become unable to depend on himself to perform a job or perform another job and settle in it, and his ability to do so has decreased as a result An organic, mental or sensory deficiency or the result of a birth deficit from birth, "and the disabled UAE legislator defined in the Persons with Special Needs Law No. (29) for the year 2006 that:" Every person who suffers from a total or partial deficiency or imbalance in a stable or temporary manner in his physical or sensory capabilities Or mental, communicative, educational or psychological to the extent that reduces the possibility of meeting his regular requirements in conditions of his likes without those with special needs ").

It is not necessary for this crime to reach the perpetrator to reach one of the goals for which he initiated his criminal behavior, namely: influencing, directing, and inciting to commit a crime, then it is sufficient for the perpetrator to seek this and his endeavor has not succeeded, and each of these goals has a different meaning, even if all of them agree that their impact is of a moral nature on Persons of criminal capacity have, either incomplete or non-existent by virtue of being either young, or having mental or psychological impairments. Influence means that pornographic content has achieved a result of the recipient and itchy who has a desire to commit a criminal offense. As for guidance, it is only counseling through the pornographic content of these persons in order to commit a crime. Incitement is pregnancy or attempted pregnancy and induction through pornographic content in order to commit a crime (Al-Muhammadi, 2015).

With regard to the moral pillar of this crime, if the Qatari legislator does not explicitly require that this crime was committed intentionally, this crime does not happen accidentally by mistake; Knowledge of the elements of the crime as stated in the text is necessary, in addition to the element of will, and in this crime the will is focused on the will of the criminal act, since this crime occurs as soon as it actually took place and the legislator did not require verification of a result, as it is from the group of formal crimes, the legislator did not stop in this crime With a general criminal intent, but rather a special criminal intent in it, which is represented in the goals that the legislator requires in order to commit the crime, which is represented in the perpetrator's endeavor to influence those who have not reached eighteen years of age, or to direct or incite him to commit a crime, and these goals that must The perpetrator wanted it only as a special criminal intent. (Al-Sharif, 2002).

The second branch: The criminalization of child sexual exploitation in the Anti-Human Trafficking Law 
Commitment of human trafficking crimes by criminal organizations via the Internet The crime of sex trafficking and child prostitution is one of the most crimes committed in this way, and some legislation criminalized human trafficking via the Internet in electronic crime legislation. (According to the text of Article 17 of the UAE Information Technology Crime Law, anyone who creates a website or publishes information on the information network or one of the information technology means for the purpose of trafficking in persons or facilitating dealing with it, shall be punished with temporary imprisonment.)

The Jordanian e-crime law did not criminalize human trafficking via the Internet, but the Qatari legislator criminalized human trafficking in the Qatari Human Trafficking Law No. (15) for the year 2011 whatever the means used in that, and the Qatari legislator criminalized the sexual exploitation of children in this law, as it was stated in Article (2) of this law, "Anyone who uses in any way a natural person, transfers, delivers, harbores, receives, or receives it, is considered a perpetrator of trafficking in human beings, whether within the state or across its national borders, if this is done through the use of force or Violence or threats thereof, or by kidnapping, fraud, deception, abuse of power, or exploitation of a state of weakness or need, or a promise to give or receive money or benefits in exchange for obtaining the consent of a person to trade in another person who has control over him, and that is all if they are These acts with the intent to exploit whatever forms of it including exploitation in prostitution or other forms of sexual exploitation, child pornography, begging, forced labor, servitude, slavery, or practices similar to slavery or servitude, or Eradication of human organs or tissues, or part thereof ..." ".

From the foregoing, it is clear to us that one of the forms of crimes of human trafficking attracting people under the age of eighteen (children) to exploit them in prostitution, or any form of sexual exploitation, and polarization means attraction, which can be achieved by any means of grooming, including electronic means And, this crime occurs as soon as polarization of this group is achieved for the purpose of exploitation in prostitution, or sexual exploitation, even if this is not done.

And the question that imposes itself: "What is the law applicable to the incident in which a child is being attracted electronically for the purpose of sexual exploitation or prostitution? Is the text of Article (7) of the Qatar Electronic Crime Law punishable by imprisonment for a period not exceeding five years? Years, and with a fine not exceeding $(500,000)$ five hundred thousand riyals, or is it subject to the provision of Article (14) of the Qatari Anti-Human Trafficking Law that punishes the recruitment of those under eighteen years of age for sexual exploitation, or prostitution, he is punished by imprisonment For a period not exceeding seven years and with a fine not exceeding $(250,000)$ two hundred and fifty thousand riyals, whoever commits one of the crimes of human trafficking stipulated in Article (2) of this law.?

In the opinion of the researcher, it is first to apply the most severe punishment to the perpetrator of this crime, given the significant effects of these crimes on the child and society, and until the perpetrator of the crime through him to others not to commit any crime related to children, therefore the researcher sees the application of the article text of Article (7) of the Crime Law Qatari e-mail, because it has a more severe penalty, taking into account also the harsh penalties mentioned in Article (15) of the Anti-Human Trafficking Law, which states that: "A penalty of imprisonment for a period not exceeding fifteen years and a fine not exceeding $(300,000)$ Three hundred thousand riyals, whoever commits the crime of trafficking in human beings in any of the following cases: "If the victim is a female or a child, a person without a right, or with a disability."

Therefore, it was necessary to receive a text in the Electronic Crime Law or the Qatari Anti-Human Trafficking Law indicating the application of the most severe punishment to the perpetrators of sexual exploitation crimes for children, according to what is stipulated in the Jordanian legislation where Article (15) of the Jordanian Human Trafficking Prevention Law stipulates that That: "Notwithstanding what is stated in this law, the court must apply any more severe punishment stipulated in any other law." As the original penalty mentioned in the Jordanian electronic crime law is more severe than the punishment mentioned in the law to prevent trafficking in human beings, the maximum limit for hard labor in the electronic crime law is fifteen years, while the maximum limit in the law to prevent trafficking is ten years, but the foregoing is true, if not Article (15) of the Cyber Crime Law stipulates that "Whoever commits any crime punishable by virtue of any legislation in force using the information network, or any information system, or website, or subscribes, interferes, or incites to commit it, shall be punished with the prescribed penalty." In that legislation. " This means that any crime not mentioned in the electronic crime law is committed using an electronic means to which the provision of this legislation applies, even if a description of the criminal descriptions contained in the electronic crime law applies to it, and since the electronic crime law does not contain criminalization of human trafficking through electronic means, then The Human Trafficking Prevention Law is the law applicable to the facts in which people are electronically recruited for trafficking and sexual exploitation.

Through the foregoing and after reviewing the legal rules approved by the Qatari legislator as protection for the child from sexual exploitation through electronic means, we find that the legislator has suffered in some respects, while some other aspects have been marred by a lack of criminalization, but in general we find that the Qatari legislator has followed the agreements and treaties The International Special Committee on Child Protection from Electronic Sexual Exploitation, especially in light of the technological and information development taking 
place in the world that helped the spread of these crimes, and the researcher believes that the electronic crime law contains extensive texts that were able to surround the legal protection of the child from sexual exploitation through electronic means.

\section{Conclusion, findings and recommendations}

In conclusion, this topic was discussed, analyzed and compared through reviewing the legal rules for crimes of electronic exploitation of children in the Qatari legislative system, and reviewing what related to this topic what was mentioned in the relevant comparative legislation. The research focused on addressing the topic of electronic sexual exploitation of children as it is one of the most prominent forms Child abuse and exploitation. Sexual exploitation of children through electronic means and the criminal responsibility of the perpetrators because it has become a global problem for its widespread spread due to the ease of committing and carrying it out and all efforts made to combat it have not succeeded, it has become a global epidemic that has spread out of the limits of control and has become an industry It spread and spread as it generates huge profits for its perpetrators, so the research sought to define the concept of sexual exploitation of children through electronic means and the objective provisions governing this topic. In addition to addressing the criminal responsibility and the penalties prescribed for the perpetrators of these crimes.

After the researcher reviewed this topic in most of its aspects with research and analysis, the researcher reached a set of results and recommendations, which can be summarized as follows:

\section{First: the results}

Based on the above, and after I explained all the details of the research topic, I have reached the following conclusions:

1- The crime of electronic sexual exploitation of a child is one of the newly developed crimes that use the network to facilitate its commission, and like that, internet crimes differ from traditional crime and it has many characteristics, the most important of which is that it is a hidden crime that occurs while the perpetrator is on the network and it is a crime that transcends the geographical borders where it can occur In one country, and its result is achieved in another country, in addition to that, the perpetrator is difficult to reach due to lack of experience by the security and judicial agencies, in addition to the fact that the perpetrator does not leave material effects indicating it, therefore they are crimes characterized by the difficulty of investigation, verification and prosecution because the detection of these crimes requires familiarity with matters Technical and technical services of the police and the judiciary.

2- That the Qatari legislator has handled cyber pornography according to two criteria. The first general criminalizes any act related to prostitution and pornography. The second dealt with child pornography.

3- The crimes of sexual exploitation of children in terms of pillars share with traditional crimes, as the perpetrator must have the intention, intent, and criminal motive - the intended purpose of the act, whether or not the result was achieved, in a manner consistent with the nature of the digital or electronic environment - based on science The will - the moral pillar in addition to the public act - the physical pillar - in order to criminalize his act and then punish him.

4- The Qatari legislator did not address in the electronic crime law any definition that clarifies the nature and nature of electronic crime in its general concept (including crimes of sexual exploitation of children), which is critical as this may lead to creating a vacuum represented by: the blurring of the concept of this type of crime and thus creating a legal gap related to What is crime and its characteristics?

5- That the crime of sexual exploitation of children is a crime that carries a great risk to children in particular and society in general, and it is one of the most dangerous types of electronic crimes that have emerged and spread around the world with the emergence and development of high-tech means of communication, including the widespread use of computers and the Internet.

6- All previous legislations agree to criminalize and combat all acts directed against children over the Internet that aim to sexual exploitation.

7- The Qatari legislator has criminalized in the electronic crime law any act or act that affects children sexually in a way that closely matches the rules that came with international legislation, and this is a general path that is welcome. However, the researchers concluded that the text of its paragraphs did not fulfill some of the issues related to the actions that make up the material pillar of crimes.

8- The Qatari legislator in the Cyber Crime Law did not address most of the child pornography crimes, especially against children. It did not address the crime of intentional viewing of pornographic acts involving children or the actions of parents or guardians who consent to the participation of their children in pornographic material, nor the criminalization of grooming children for sexual acts. Like other crimes regulated by law, these crimes or acts pose a threat to children or the mentally or psychologically handicapped and to society as well.

9- The Qatari legislator did not put in place special and independent texts that deal with the crimes that are expected to be committed by the provider, supplier and contractor of the information network service. It is an unlawful 
crime considered as a criminal offense for the information network service providers, suppliers, contractors and publishers, if this is proven.

10- The Arab countries are late in caring and alerting to the dangers of sexual exploitation of children via the internet, and this is not evidenced by the recentness of their legislation in this regard, unlike the western countries that have followed their legislation along with the development of the means of communication and information technology and were constantly amending their legislation whenever the need arises. .

11- The legislation in question differed in explaining the forms of activity that are one of the elements of the material pillar, as well as among them in terms of the type of intent required for the occurrence of the crime, where some were satisfied with the general intent, while some required the special intent to the side of the year.

\section{Second: Recommendations}

Based on the foregoing, the researcher wishes to the relevant official authorities to consider studying the recommendations that this research has reached and adopt what is achievable from them, and they are as follows: 1- The necessity of stipulating a definition that clarifies the nature and nature of cybercrime, a path taken by most of the relevant national and international legislation in this field.

2- We recommend the Qatari legislator to the necessity of issuing a special law to protect children to activate what is mentioned in the Convention on the Rights of the Child.

3- The child's responsibility - the subject of work or pornography - must be indicated. As it was addressed by some international legislation and adapted to the effect that the child is not responsible and should not be seen or treated as a criminal or perpetrator of a guilty criminal act, because of the effect of the act of exploiting it, decreasing or tainted by his will in a manner that evokes his criminal responsibility, as this is done with what came International agreements that aim to establish child protection.

4- The researcher wishes to monitor the reality of the Iraqi child and his needs, and to identify the gaps in the services and programs provided to him, and to reveal practices that negatively affect children and intensify efforts to address them.

5- The researcher wishes to publish information related to child abuse, its symptoms, characteristics and negative effects in the various available media and communication extensively, so that all members of society can identify and report cases of abuse and exploitation of children.

6- The researcher wishes to include legal texts that address and organize the work of the information network service providers, suppliers, contractors and publishers to fill the legislative void in this aspect.

7- The researcher wishes to draft a text in Article Seven of the Qatari Cyber Crime Law to compel companies providing telecommunications and internet services to block pornographic websites, which will have a significant and effective role in preventing the risks of child victims of sexual exploitation via the Internet.

8- The necessity of stipulating in the electronic crime law to protect children who are physically or mentally disabled from sexual exploitation and not to mention the child in general.

\section{List of references and sources}

\section{First: books}

- Al-Asadi, Lina Muhammad, The effectiveness of the provisions of the criminal law in combating information crime, Amman, Dar Al-Hamid for Publishing and Distribution, 2015.

- Bawadi, Hassanein Al-Muhammadi, Child Rights between Islamic Sharia and International Law, Alexandria, Dar Al-Fikr Al-Jami'a, 2015.

- Physical, Child and Adolescent Psychology and Fundamental Facts, Beirut, Arab Science House, 1994.

- Hussein, Bushra Soliman, Criminal Protection for Childhood, PhD thesis, University of Baghdad, 1999.

- Al-Sharif, Omar, degrees of criminal intent, Cairo, Dar Al-Nahda Al-Arabiya, First Edition, 2002.

- Tobasi, Suheir Amin, Restorative Justice for Juveniles in Jordanian Criminal Laws, Amman, Dar Al-Thaqafa for Distribution and Publishing, 2005.

- Attia, Hamdi Rajab, Child Criminal Responsibility in the Legislations of Arab Countries and Islamic Sharia, Cairo, Arab Renaissance House, 1998.

- Al-Muhtar, Bassam Atef, Bassam Atef, Child Exploitation: Challenges and Solutions, Beirut, Al-Halabi Human Rights Publications, 2008.

- Nile, Brahim Eid, Criminal Protection for a Child's Display of Sexual Abuse, A Comparative Study between the French and Egyptian Penal Code, i 1, Dar Al-Nahda Al-Arabia, 2016.

- Al-Nawaiseh, Abdel-Elah, Information Technology Crime "Explanation of the substantive provisions in the Electronic Crime Law, Wael House for Publishing and Distribution, 2017, 2015.

- Second: university theses

- Ibrahim, Adel, Crimes of sexual exploitation of children via the Internet and methods of combating them in criminal legislation and Islamic criminal jurisprudence, Master Thesis, Al-Azhar University, 2013. 
- Shwish, Lara Muhammad, Child Sexual Exploitation, Master Thesis, University of Damascus, Syria, 2017.

- Saker, Ahmed Kailan Abdullah, Crimes Arising from Computer Misuse, MA Thesis, University of Baghdad, 2002.

- Al-Obaidi, Bushra Salman, International Criminal Violations of Children's Rights, PhD thesis, University of Baghdad, 2004.

- Third: Journal, research and seminars

- Khalil, Deca, Children in Trafficking Positions: Definition, International Standards, and Programmatic Frameworks, Scientific Workshop on Combating Trafficking in Persons, held during the period 19-23 / 1/2006, Riyadh, 2006.

\section{- Abdelkrim}

- Darwish, The Future of a Juvenile Delinquent as Society Wants, Research in the Arab Journal of Police Sciences, No. 22, Cairo, 2016.

- $\quad$ Abdul, Rashkhalil, Sexual Exploitation of Children Online, Al-Fateh Magazine, Number 27, 2006.

- Al-Qadhahi, Mashaal bin Abdullah, Pornography and its Consequences, Saudi Arabia, Seville's Treasures for Publishing and Distribution, 2005.

- Al-Marri, Amal Ali Muhammad, The Role of Human Rights Institutions to Protect Children from the Dangers of the Internet, Workshop ((Protecting Children from the Dangers of the Internet)), Doha, 2012 


\title{
The Attitudes of the Students Enrolled in Jordanian Universities towards Distance Education during the Coronavirus Pandemic
}

\author{
Nesreen Nabil Rawhe Atieh
}

\begin{abstract}
The study aimed measure the attitudes of the students enrolled in Jordanian universities towards distance education during the Coronavirus pandemic based on three constructs (educational process, evaluation and tests, collaboration and social influence). The sample consists from 150students for university of Jordan. The study used questionnaire. The study found that the students' attitudes towardsdistance education during the Coronavirus pandemic is medium and positive includes (Educational Process Items, Evaluation and Test Items, Collaboration and Social Influence Items). The study also found that there are no significant differences in distance education during the Coronavirus pandemic related to (Gender, Living Place, Education) . the study recommend to provide all the technical and technical requirements for the distance learning process, and to help students acquire appropriate means for distance learning, especially since some of these technologies are expensive.
\end{abstract}

Keywords: Distance Education, Coronavirus Pandemic

DOI: $10.7176 / \mathrm{JEP} / 11-25-07$

Publication date:September $30^{\text {th }} 2020$

\section{Introduction}

The Coronavirus pandemic is considered a global crisis. This virus spread in a short time. It affected the lives and life style of people in many countries. It affected people in social, political, cultural, economic, educational, and technological areas. Hence, many governments took several preventive measures to prevent this virus from spreading. Such measures aim at reducing the severity of the impact of this pandemic. They include:enforcing curfew, and implementingsocial distance policies. They includethe closure of the land, air and maritime borders. They include: the suspension ofactivities in many sectors, including the economic and educational sectors.

Due to this virus, the educational sector has been facing major challenges. The Coronavirus pandemic has many impacts on the educational system and process. Such impacts include: academic and psychological impacts. They include positive and negative impacts. Most of the impacts of the Coronavirus pandemic on the educational sector are considered negative impacts. For instance, the Coronavirus pandemic forced many educational institutions to close temporarily. Such temporary closure led to the spread of concerns among many students. In the light of such conditions, many universities cancelled or postponed many activities and events in the aim of preventing the spread of this virus among students and administrative and academic staff.

The Jordanian Ministry of Higher Education and Scientific Research decided to provide university and school students with online education through using the e-learning platform. That was decided to ensure that the social distance policy is implemented and keep providing students with education. Through using thee-learning platforms, all the Jordanian public and private educational institutions were closed temporarily. However, they kept delivering education to all students during the Coronavirus pandemic. That was done to cover the targeted curricula. All courses were taught through using the e-learning platforms. Tests were administered through using the e-learning platforms. The e-learning platforms were used in accordance with special mechanisms. Through implementing such mechanisms, teachers kept communicating with students and the relevant burdens were reduced.

Distance education via modern communication methods aim at providing students with equal educational opportunities. That is needed in the light of enforcing curfew, and implementing social distance policies during the coronavirus pandemic. Distance education via modern communication methods serves as the only optionfor delivering education during this pandemic. It enables students to adopt a self-learning approach. It enables educational institutions to keep delivering education to students.However, it is associated with several problems. For instance, it may lead to experiencing social isolation. It reduces the extent of social interaction between the ones involved in the educational process. It deprives individuals from establishing social relationships with others. It doesn't ensure that all students are provided with equal opportunities to benefit from e-learning platform.

Distance education is a complex term. To illustrate more, there are several variables that affect the quality of this education. Such variables include: human, technical and administrative variables. The universities that deliver distance education of high quality are the ones that take all those variables into consideration. Refraining from taking any variable into consideration shall negatively affect the quality of such education (Al-Saleh, 2006).

Coronavirus has been spreading for a long period of time. Till today, all countries failed to find a cure for the Coronavirus. Hence, people start tocope with this virus in order for the national and global economy to recover. In the light of such conditions, university students should cope with this situation. That shall enable them to avoid stress. Through distance education, people of all social categories shall definitely receive education. Through such education, numerous students shall receive education. 